Literatura y Lingüística $\mathrm{N}^{\circ} 24$

ISSN 0716-5811 / pp. 61-79

\title{
Discurso, subversión y rebeldía de género en Infamante Electra de Benjamín Galemiri*
}

\author{
Marcela Medina Bravo**
}

\section{Resumen}

Se aborda el texto Infamante Electra, de Benjamín Galemiri (chileno), como un discurso dialógico donde se entrecruzan una serie de modalidades lingüísticas transgresoras que se actualizan en el Chile contemporáneo, a partir del conflicto/ trágico (Mito de Electra) cuyo escenario despliega una relación entre poder y sexualidad que transforma a la pareja (padre/hija) en un diálogo de incomunicación textual que configura un espacio semiótico nuevo, cuyas categorías de análisis crítico pueden relacionarse a cuestiones de género y sociedad. Se establece como sustento de análisis textual el entrecruce y desplazamiento de la dicotomía sintagma/paradigma.

Palabras clave: Género, poder, discurso, texto dramático, intertextualidad, Sintagma/paradigma

\section{Discourse, subversion and rebelliousness of gender in Infamante Electra by Benjamín Galemiri}

Abstract

The text The Infamous Electra, of Benjamin Galemiri (Chilean) is analysed as a dialogic discourse where a number of transgresor linguistic forms are crossed which are updated in the contemporary Chile, based on the conflict / tragic point view (Myth of Electra) whose stage displays a relationship between power and sexuality that transforms the couple (Father / daughter) into a dialogue of textual confinement which sets a new semiotic space, whose categories of critical analysis may be related to gender and society issues. It is established as a support of the textual analysis the shift and the crossover of the sintagm / paradigm dichotomy.

Keywords: Gender, power, speech, dramatic text, intertextuality, Syntagm/ paradigm

Recibido: 24-03-2011Ａceptado: 11-04-2011

Artículo producido para el curso "Retórica feminista", Programa Magíster en Género, CEGECAL, U. de Chile, 2010

** Magister Artium mención Literatura. Profesora del Programa de Bachillerato en Ciencias y Humanidades Usach, Departamento de lingüística y literatura, Usach, Programa de Educación Media y Pedagogía en Castellano Universidad Católica Silva Henríquez. marcela.medina@usach.cl 
Discurso, subversión y rebeldía de género en Infamante Electra de Benjamín Galemiri /

Marcela Medina Bravo

\section{Introducción}

- Benjamín Galemiri está considerado como el dramaturgo chileno más importante surgido en la década de los $90^{1}$; se lo ha señalado como una de las voces más interesantes y singulares de la dramaturgia chilena de los últimos años. Al respecto, Matthias Langhoff (director teatral francés) señala: "Las obras de Galemiri son desconcertantes y llenas de enigmas. Repletas de «historias» y de «Historia». No conocen la calma en su forma cerrada. El teatro deviene cine, el cine deviene teatro. La filosofía, el antiguo Testamento, los cómics, la pornografía, el psicoanálisis y las jergas de la calle se entremezclan y se transforman en imágenes de batallas nunca capituladas. Los personajes de Galemiri se golpean, se ensucian, se persiguen, se violan con la palabra. Detrás de las palabras vive el horror insensato que empuja a los hombres contra los hombres. El horror cotidiano, el de hoy en día, el de ayer, el de la herencia". (1)

- ¿Cómo se manifiesta este uso caótico de la palabra y conceptual a la vez, y cómo se entiende una perspectiva de género en sus textos dramáticos? Estos últimos parten de un especial uso del lenguaje en la confrontación de sus personajes y con ello nos acercamos a nuestra primera opción de análisis, que tiene relación con la conceptualización de Texto dramático: que tradicionalmente representa algún conflicto de la "vida" a partir del diálogo entre los personajes, en un discurso de constante tensión.

- El fin del texto dramático es la representación de sus contenidos frente a un público (deviene en texto espectacular), con ello se completa la figura del género literario. Sin embargo, dadas las condiciones de la propuesta dramatúrgica de Galemiri, existe un exacerbado y caótico uso de la palabra representada en una ideología particular. Este punto de inflexión es el que se decide abordar dejando de lado la figura "espectacular" y así postular un trabajo lingüístico de significado en Infamante...

- Lo anterior proporciona un campo muy seductor para visualizar un enfoque semántico de resignificación de la categoría de género. Pues a primera vista, trasunta una particular visión de mundo, que se hace cargo del discurso, no para recrear, sino para subvertir cánones, tradiciones y hegemonías de género, obviamente cuestiones vinculadas al poder.

1 Guerrero, "Prólogo" (2003), Antología esencial, Santiago, EDEBE 
Infamante Electra propone una visión del conflicto padre/hija a través de un discurso dialogado, donde se entrecruzan poderes. El texto muestra el encarcelamiento del padre por motivos de corrupción, y la defensoría de la hija, quien no sólo cuestiona la transgresión patriarcal en el modelo político, sino que también en el modelo filial, puesto que éste ha negado la existencia (nombre) de su madre. El mito de Electra que subyace se ve condicionado a la no existencia de la figura de la madre, impuesta por el padre, y a la relación con los modos políticos y culturales del Chile contemporáneo.

\section{Corpus teórico}

Este trabajo comienza, a modo genérico, con la tesis que manifiesta que los discursos objetos de nuestra atención crítica pueden volcarse en continentes textuales de distinta factura semiótica y por ende nos configuran un espacio donde los discursos exteriores (meta-relatos, ideologías) son con éstos, y con ellos, por lo tanto son también parte de su texto, de lo que resulta, una idea que se pronuncia a favor no solo de la conveniencia sino de la inevitabilidad de una crítica intertextual ${ }^{2}$. Es por ello que el campo de acción discursivo/dialógico propuesto por el autor permite relacionar las categorías de discurso, poder y género, a través del concepto rebeldía y su relación con los polos metafórico y metonímico; estas dos formas retóricas se relacionan con los tipos del discurso y del género, en este caso: Metáfora, sustitución, masculino, padre, lógica lineal, escritural, visual, vertical. Metonimia, acumulación, proceso, femenino, lógica múltiple, oral, auditiva, horizontal, luego está la alegoría, que es una figura más compleja que trabaja con la simultaneidad.

En el psicoanálisis la metáfora es desplazadora, en cambio la metonimia es acumulativa y permite que exista la multiplicidad.

En una lectura que analoga los procesos sociales antes descriptos con la metonimia lingüística, Butler sostiene que "el campo de las relaciones diferenciales de las cuales emergen todas y cada una de las identidades particulares debe ser ilimitado. Más aún, la 'incompletitud' de todas y cada una de las identidades es el resultado directo de su emergencia diferencial: ninguna identidad particular puede emerger sin suponer y proclamar la exclusión de otras, y esta exclusión constitutiva o antagonismo es la misma condición compartida de toda constitución de identidad.

2 Grinor Rojo, (2001) Diez tesis sobre la crítica, Santiago, Editorial Lom. 
Discurso, subversión y rebeldía de género en Infamante Electra de Benjamín Galemiri /

Marcela Medina Bravo

La incompletitud de la posición del sujeto, entendida como "el fracaso de cualquier articulación en particular para describir a la población que representa" y, por otro lado, también como el hecho de que "cada sujeto está constituido sobre diferencias y lo que es producido como el 'exterior constitutivo' del sujeto nunca puede pasar a ser totalmente interno o inmanente" es la base discursiva que anida en el ideal político de la semiosis nunca cancelada de la democracia radical y pluralista.

El antagonismo no es binario. La emergencia diferencial transcurre en la cadena significante sin cierre que produce la concatenación de las identidades particulares, cuya universalidad radica en que todas comparten "ser lo que las demás no son". Pero, si las diferencias no lo son en relación a términos positivos entre los cuales establecerse, son sólo pura diferencia. Se subraya la fundamental importancia de la metáfora vs. la metonimia en relación a una teoría de la diferencia como sistema político. ${ }^{3}$

De esta forma, el discurso de Galemiri en Infamante Electra, puede entenderse como "un lugar donde se ejerce la creatividad, lugar de contextualización imprevisible que confiere nuevos valores a las unidades de la lengua. Es una suerte de polisemización de una unidad léxica (palabra)" integradas bajo las formas de la metáfora y la metonimia. Ejemplo: mujer, hija, descendiente, dependiente, que se desplazan en hombre, ascendiente, independiente, etc. Y viceversa.

Esta definición se acerca a la tesis fundamental foucaltiana (acercamiento político) y que es la que se propone como base de análisis de Infamante...: "en toda sociedad, la producción de discurso está a la vez controlada, seleccionada y redistribuida por un cierto número de procedimientos que tiene la función de conjurar poderes y peligros, dominar el acontecimiento aleatorio y esquivar su pesada y terrible materialidad". ${ }^{5}$

Y tal como como dice Spivak ${ }^{6}$ : las teorías post estructuralistas (Derridá por ejemplo) "solo pueden trabajar, sin cesar, en conceptos metáforas que de manera deliberada establecen y ponen en juego un sistema de significados diferentes (...) así el proyecto colectivo de nuestra crítica literaria feminista siempre debe(rá) (el paréntesis es mío) ser reescribir

3 Butler, Judith en: http://www.ft.org.ar/estrategia/ei20/ei20feminismo.htm

4 Maingueneau, (1989), Introducción a los métodos de análisis de discurso, Buenos Aires, Hachette, p. 16.

5 Foucault (1980), El orden del discurso, segunda edición, Madrid, Tusquet editores.

6 Spivak (2008), El desplazamiento y el discurso de la mujer, p. 174.

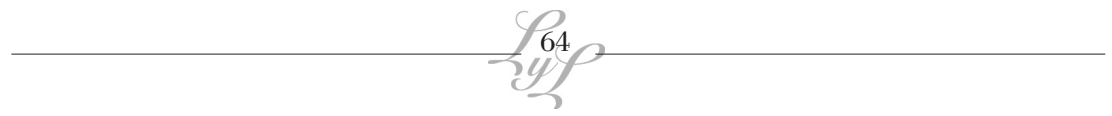


el texto social de modo que las diferencias históricas y textuales operen juntas."

Qué duda cabe que el carácter literario de Electra es la preocupación de una serie importante de obras dramáticas (Orestiada de Esquilo, Electra de Sófocles, Electra de Eurípides, Mourning Becomes Electra de O`Neill, Las Moscas de Sartre, etc.). Para la propuesta de análisis será la sustancia del mito y la definición sicoanalítica de Jung que nos refiere a las obras de la antigua Grecia. Electra soltera y todavía de duelo por su padre Agamenón, que ha sido asesinado mucho antes por su madre Clitemnestra y el amante de ésta, alienta a su hermano Orestes a matar a su madre.

En psicoanálisis es el amor incondicional por su padre y el odio hacia su madre que hicieron de Electra una figura retomada y reinventada. C.G. Jung, discípulo de Freud, utilizó el mito para simbolizar la fijación afectiva de la niña en la figura del padre y la competencia con la madre, es un proceso normal en la formación psíquica y emocional de los infantes y su resolución comprende el correcto desarrollo y orientación de la sexualidad y su rol social. En este punto, comienza la subversión rebelde de Galemiri y su Infamante donde la estructura significado propuesta por Jung es la que se transgrede a partir de las estrategias discursivas que acercan a la incomunicación y por ende, al desplazamiento del paradigma y el sintagma entre los conceptos de habla del padre y la hija.

Se propone que Infamante Electra representa a través de su discurso dramático una transgresión del mito clásico acuñado por Jung -una hija de deseo inconsciente libidinal de su padre- representado en las categorías del poder, político y género actuales. Este conflicto se genera a partir de la acción dialógica y cuyo mayor punto de interés es la serie de estrategias lingüístico/semánticas, que cada personaje tiene y el ingenio que utilizan para persuadir y hegemonizar al otro, en un constante desplazamiento, al nivel de las categorías de la metáfora y la metonimia.

Por lo tanto, la hipótesis a trabajar dice que se aborda el texto como un discurso dialógico donde se entrecruzan una serie de modalidades lingüísticas transgresoras que se actualizan en el Chile contemporáneo. A partir del conflicto/trágico (mito de Electra) y que en este caso se propone como una relación entre poder y sexualidad que transforman a la pareja (padre e hija) en una incomunicación textual que configura un espacio semiótico particular cuyas categorías de análisis crítico pueden relacionarse a las cuestiones de género y sociedad tanto en el ámbito político como filial. 
Discurso, subversión y rebeldía de género en Infamante Electra de Benjamín Galemiri /

Marcela Medina Bravo

La primera lectura del texto muestra el enfrentamiento de dos personajes (hombre y mujer), cuyo espacio relacional está dado, en primera instancia por ser padre e hija y por la situación de cárcel del primero y del ejercicio defensor de la segunda. Es allí donde aparece el primer conflicto incomunicacional, pues la defensora se ha convertido en acusadora y aprovecha tal situación para entronizar una suerte de chantaje emocional hacia el padre, cuya orientación va en directa relación con la eliminación (nominal) por parte de éste (objetiva y subjetiva) de la figura de la madre.

Esta situación, en cuanto diálogo, los personajes no se escuchan, no se comunican. Sus relaciones se condicionan y se acercan sólo como una agónica forma discursiva en la dominación/ culpabilización, de uno sobre el otro.

DAFNE: Padre, Ud. nunca me quiso!

Me detracto

Parece una asquerosa película de Robert Siodmak.

Balbucea la aurora

Sus siempre banales seguidores se aproximan

Usted y yo solos, como en un western de Budd Boetticher

El huracán está cerca

Mezquino

Padre, usted nunca me amó

Yo lo acuso de dejarme bullente

Sola

Desvalida

Aullando

Noche tras noche

Y esperé (...)

JOSHUA: Perdone licenciada... es la maldita brisa pesada de la tarde... Es el polen... Es la tierra que levantan las muchachas insurgentes. Afuera está el cielo cargado, llueve tenuemente...

\section{El mito y la rebeldía}

El título de la obra se sitúa ya en el ámbito de paradoja y desplazamiento, Infamante Electra. Esta última en el texto se la nomina como Dafne que, a su vez, simboliza el rechazo en el mito griego (véase el Mito de Apolo y Dafne). Ella debe ser la defensora legal, institucional, y emocional del padre, y sin embargo lo rechaza, increpa y objeta sólo por el deseo rebelde de saber quién fue su madre. 
JOSHUA: ¿Cuánto me costará mi libertad?

DAFNE: Algo que te duela mucho. El nombre de mi verdadera madre.

Aparece así lo Infame:, "que carece de honra, crédito y estimación (R.A.E.)", transformado en Infamante, adjetivación por el acto rebelde permanente sobre la institución legal, paterna y emocional. Electra ama al padre / Dafne lo rechaza, un primer desplazamiento semántico nominal a partir de la rebeldía.

El rechazo o rebeldía "como primera orientación semántica será a partir de los orígenes del término que produjo derivados con significaciones -semas- tales como curva, entorno, vuelta, retorno (...) Bajo la influencia del italiano la idea de un movimiento circular y por extensión de un retorno temporal. Volta significa vuelco (...) la unidad profunda de estas evoluciones etimológicas parten de una idea matriz "torcer, enrollar, envolver". Y, aún más, siguiendo a Kristeva, la acepción moderna de la palabra: rebelar derivó de las palabras italianas "volcar" e intercambiar" lo que implica de entrada un rechazo a la autoridad, cuestión política que es, en estricto rigor, oposición (dejar un partido), abjurar (dejar una creencia), desviarse (respecto de una dependencia), guerra que supone rebelde, rebelión que se usa también en el ámbito psicológico. (KRISTEVA, 1990, pp. 14-15)

Si se relaciona lo anterior al término Infamante, se percibe que la sujeto en cuestión carece de honra, crédito y estimación, pues no actúa como abogada y de las más connotadas en el país, con serias aspiraciones a cargos de importancia en el nivel jurídico y estatal. Otra subversión.

Todo lo anterior presenta una visión que podemos relacionar así: El mito de defensa del padre por parte de la hija y venganza de la madre (Clitemnestra) se subvierte a partir de la rebeldía/infame de Dafne (ya sugerimos que ella representa el rechazo al dios Apolo en el mito griego), rechazo a la autoridad a partir de una cuestión de poder: abogada, libre, pública. Se desplaza el poder a lo femenino y éste condiciona y subyuga a lo masculino que no es nada menos que su padre, es decir, se rebela contra la institución padre/Estado.

En este escenario, la cuestión paradigma/sintagma, metáfora, símbolo (padre, institución, Estado, etc.), se desplazan en la transgresión de género, pues se representa la mujer, quien da señales de poder atribuibles solo al Estado, la protección y la institucionalidad. Electra/Dafne pro- 
Discurso, subversión y rebeldía de género en Infamante Electra de Benjamín Galemiri /

Marcela Medina Bravo

tagonista mujer rebobina las relaciones propuestas por el mito clásico (nótese la palabra clásico y lo que ello significa) para instalarse en una subversión, como una sujeto autónoma, rebelde, lo que a su vez rompe con las categorías clásicas del género (y del mito).

El paradigma mujer, hija, protegida (categorías clásicas del género como constructo cultural) se han desplazado a padre, hijo/protegido. Se añade a esto la cuestión semántica de otro concepto subvertido: la dicotomía Fama/infame. Mujer famosa carente, convertida en infame, es decir sin fama. Otra rebeldía u otro desplazamiento.

En resumen, Dafne, la hija, debe defenderlo, no solo por serlo, sino que también por ser ella una abogada de renombre, institucionalmente reconocida y pública. En este caso, la condición de hija y abogada sólo se reconoce en la palabra DEBO.

DAFNE: Me encantaría aceptar una pequeña discusión sociológica con Ud., pero debo salvarlo del cadalso, de la quema, del fusilamiento, de la cadena perpetua, usted elija".

(...) Por lo demás, su rictus amargo es todo lo que mantendrá durante su juicio oral. Le regalaré este pesado dossier en su contra, para que sufra el frío abandono que yo misma sufrí de Ud... Va dejando huellas húmedas por todas partes. Y ahora responda... ¿qué sabe de la senadora pelirroja que presentó una de las querellas contra Ud. por la malversación de fondos?

\section{Subversión/Rebeldía}

Entendiendo la rebeldía como leiv motiv en el actuar de Dafne se configura un espacio semiótico original en la escritura de Galimieri, pues la actualización de este mito, así entendido, no sólo se ocupa de la conflictiva relación padre hija en términos de filiación, sino también en términos políticos que tiene que ver directamente con la institucionalidad, que en este caso, toma en cuenta la interioridad morfológica condicionada al "deber ser", cuestión ampliamente estudiada en los inicios de los estudios de género (una mujer no nace, se hace, Beauvoir).

La escritura de Galimieri se contextualiza en un espacio contemporáneo en el Chile actual, es decir el poder político enraizado no sólo en la figura del padre, aun cuando ésta sea madre (Bachelet), abogado, sino también en múltiples alusiones a la ideología de la incomunicación, desmitificación, de las mass media, de la manipulación de la información, 
del posicionamiento social, de la demagogia política, la tergiversación, los DD.HH", etc ${ }^{7}$ :

JOSHUA:

¿Oyó?

Es la inútil y maldita revuelta que se avecina

Me mal interpretaron

Este país apesta

Yo apesto

Usted apesta

¿Los estoy embaucando con mi humor gris?

Usted se ve ligeramente embrollada con su falda tweed marrón...

(...) Dónde está ese rufián que hizo gemir hasta la muerte a mi hijo en el potro?

¿en qué comisión económica se ufana ese fasho?

Chile, iahora que sufro quieren algo?

Ahora soy un lastre, lo sé

Derecho a la hoguera sin escalas

Le hablo a la conciencia criolla

Donde veo

A mi padre

A mi madre

Muerto en Villa Grimaldi

La revuelta otra vez

La destrucción, el caos nuevamente en el Chile transicional

El orden

La jerarquía

En alguna región costera

Nosotros como familia

Dafne

Un poco de dicha

La sublevación otra vez

¡Si seré imbécil!

Estoy súper solo...

Improntas metonímicas de un sujeto subvertido en hijo que sólo se reducen y se desplazan para un solo significado dado por la última frase "Estoy súper solo". Otra vez más desplazamiento, otra vez el sintagma entrecruzado con el paradigma, múltiples significantes para un solo significado.

7 Sirven, Polzenhagen et al., (2010) Cognitive, linguistics, ideology, and critical discourse analysis en The Oxford Handbook of Cognitive Linguistics, Edited by Dirk Geeraerts and Herbert Cuyckens, Paperback. 
Discurso, subversión y rebeldía de género en Infamante Electra de Benjamín Galemiri /

Marcela Medina Bravo

Dafne como hija rebelde y como sujeto mujer se instaura en el discurso y para ello se vale de estrategias textuales que entran en directa contradicción en su relación con el Padre. Una de esas estrategias, como hemos dicho, es la ruptura del significado: Mito-Padre/poder/autoridad, sistema, aparecido en el texto por el desplazamiento del significante en su discurso: Hijo, indefenso, obediente. Ella está constantemente dándole una especie de "vuelta de tuerca" a dichos significados a través de un lenguaje conceptual, caótico, que la instala en lo que hemos llamado la no existencia, lo inenarrable que corresponde a un estadio anterior al surgimiento de la figura instaurada del concepto lenguaje/ley. Se produce así el conflicto.

\section{DAFNE:}

¿quién dijo eso?

(...)

JOSHUA ALEVI:

Yo lo dije

DAFNE:

Lástima, pensé que lo había dicho alguien (cursiva mía)

Sus mecanismos, paradójicos, por así decirlo, surgen del lenguaje mismo, ella rompe con el convencionalismo lingüístico al modo de Saussure por un mecanismo también lingüístico que tiene sus raíces en la estructura profunda de su psiquis, marcadas en su cuerpo, y que aparecen en su habla: (Más adelante se verá este punto).

En una monumental sala rodeada de carísimos espejos holandeses, la ultravanidosa abogada Dafne y con justa razón ensaya teatralmente y con implacable histrionismo, aunque a veces derrocha una gestualidad pasada de moda, el alegato televisado que hará ante el jurado. Transmisión que ella ha vendido a tres canales europeos (...) su multiplicada imagen se cruza con las imágenes de las mujeres que Joshua Alevi tuvo como amantes, todas sus posibles madres.

DAFNE:

"Como proclamé, mi padre me dijo por primera vez que me quería cuando cumplió los sesenta años. Ya era demasiado tarde para todos en el mundo. Una vida vacía, un paraje de profunda belleza pero también de insultante atrocidad. No ha dicho ni una sola palabra sincera. Maldito sea tu inconstante sentido del humor, desquiciado padre.

Tengo acantonada en mi mente, aquellas conversaciones estáticas durante mi infancia, en planos habitualmente fijos para demos- 
trarme la naturaleza de tu carácter, puro remedio de tu corazón ferozmente panfletario, mientras yo seguía siendo tu criatura prisionera con ese ritmo de tus palabras, seco y nervioso, que emitía una extraña sonoridad de tu horrible caos interior, me implicaba cada vez más en tu desesperación burguesa, me recordabas patéticamente la belleza del cielo de Chile, con tu aire falsamente melancólico, aunque debo aceptar que seductor para toda aquella mujer que poseyese una espiritualidad post marxista, ya saben, de padre ausente y madre competitiva, te veía sonreír en la penumbra, austero pero no menos inspirado, era tu manera de disertar nuestra vida, luego tenía que soportar las rupturas más crueles con mi supuesta madre...

Discurso autoritario, discurso ideológico, poderoso solo en la medida del contexto. Dafne y sus debilidades, Dafne en televisión abjurando de su padre, pero solo a través de, lo que más le duele, ausencia de madre y también del padre. Reproche, tortura para ella, tortura para él. Dafne reconociendo a través de su fortaleza instaurada por su posición política y hegemónica, que está solo allí por el signo de la rebeldía, infamia y subversión política.

Sólo cuando se rebela se posiciona.

Sin embargo, se reconoce que para ser rebelde debe existir un alguien o un algo por lo cual rebelarse. Y aquí está de nuevo el desplazamiento: vuelve a ser hija, vuelve a ser "mujer", son sus sentimientos los que priman. Se reconoce en él y por lo mismo lo odia, se da cuenta que aunque sepa el nombre y quién fue su madre no puede dejar de reconocer la impronta del padre en su cuerpo, en su psiquis. Su rebeldía se ha desplazado a la máscara que no es más que evitar ser lo que siempre fue. Porque ella ama a su padre, porque se identifica con él y a su vez lo odia y para justificarse necesita un pretexto "convencional".

Reconoce en él el vacío, la vaguedad de su discurso, su hipocresía, y para ser rebelde es refrendarle que ella también puede ser vacía, ser autoritaria, ser manipuladora. A pesar de ello este ser es su complemento. Dafne termina por reconocerlo, una vez que se ha acabado el objeto de su rebeldía (condena de su padre, conocimiento de madre), vuelve a sí misma, vuelve al canon. Es así una sujeto nómade, lo que, para Gloria Blonder $^{8}$, es buscar respuestas al menos en el plano simbólico de su identidad.

8 Blonder (1998). "Género y subjetividades, avatares de una relación no evidente", en Género y epistemología: Mujeres y disciplinas, U. de Chile. pp. 1-15. 
Discurso, subversión y rebeldía de género en Infamante Electra de Benjamín Galemiri /

Marcela Medina Bravo

Nómade/desplazamiento desde la rebeldía a la sumisión identitaria convencional, normativa heterosexual, "su marca de género es parte de la economía significante hegemónica de lo masculino" (Butler citando a Wittig) ${ }^{9}$. El significante mujer/hija si bien es cierto se logró desplazar, no logra todavía encontrar una voz propia, un significado de suyo.

Fue un intento que, a la luz de Irigaray, es la posibilidad de otro lenguaje o economía significante como la única forma de evitar la marca del género, que para lo femenino no es sino la eliminación falologocéntrica de su sexo. Dafne apostó en el plano simbólico y político la necesidad de una nueva subjetividad que se rebele contra los procesos de internación cultural hegemónicos, cuestión que a la luz de lo visto solo se puede comprender en el plano de la desterritorialización de las codificaciones patriarcales. Intentó así rescatar una subjetividad en relación con la alteridad en la necesidad de que las diferencias históricas y textuales operen juntas.

Tal como dice Wittig se es perfectamente consciente del poder que posee el lenguaje para subordinar y excluir a las mujeres, es una institución que no puede modificarse de una manera radical. "El lenguaje es una de las prácticas e instituciones concretas y contingentes mantenidas por la elección del individuo y por lo tanto debilitadas por las acciones colectivas de los individuos que eligen" (Butler, 2007). Quizás podamos decir en este sentido que no hay escritura, ni voz femenina.

Para Dafne, al terminar con el proceso de rebeldía a partir, como dije, de la condena de su padre se ha quedado sola y decide lingüísticamente, metafóricamente emanciparse, e insertarse en el mundo del significado convencional.

DAFNE:

Las cosas malas se perpetúan genéticamente, padre.

Es como un código de honor, ahora esas grandes mentiras las llevo yo en mi interior, solo que las demás las ven como verdades, es como digo lo que tú me enseñaste.

Me desarma la sinceridad de tu pueblo

A veces impúdico

Yo con mi lengua cáustica y mordaz que ellos adoran

Que da a mi vida toda esa negrura.

Mi vida

Es como una puesta en escena neurótica

9 Butler, (2007), El Género en disputa, Barcelona, Paidós, p. 86. 
Siempre eficaz.

Me gustaría sentir el peso inexorable de tu condena en mi corazón.

Pero será esa la manera de separar estos dos seres llamados padre e hija.

Tiene algo de cínico

Tiene algo de placer.

Como dos amantes desplomados por una sensualidad que los sobrepasa.

El deseo de alcanzar la verdad. Rehaceré mi vida, padre

Será mi formidable demostración de voluntad.

Luego de años de odio y desesperación. Luego de extrema violencia decido ser dulce.

Vagamente reaccionaria... ( la cursiva es mía)

\section{Mascarada galemiriana}

Como se ha visto, el discurso se ubica en un escenario transgresor, rebelde y subversivo a partir del pequeño análisis de estas dos categorías. Sin embargo, para la atención del trabajo lo que importa es la relación de rebeldía de género a través del discurso dialógico y que puede según esta lectura configurarse en la figura del poder. Se trata del poder puesto como incomunicación, no como imposición, ni menos como sujeción y que se actualiza en el discurso dialógico. En efecto, existe un desplazamiento constante del sujeto "mujer poderosa" entre "los polos metafórico y metonímico, es decir podemos tener múltiples significantes para un solo significado"10

JOSHUA:

Eran para mí como la Gestapo

La CNI quiero decir

Una gestapito de bajo presupuesto

¿puedo ver a mi primogénito, el hijo de mis entrañas?

No me importa voy a esperar

Se acerca el día del fusilamiento

Pondré mi cuerpo entre las balas y tu rostro, hijo de mi carne,

Ya verás

Te mostraré un amor delirante

Dios nos tiene reservado un lugar discreto

Y estoy fuera de Villa Grimaldi

10 Jakobson, Fundamentos del Lenguaje: Los polos metafórico y metonímico, pp. 132-143. 
Discurso, subversión y rebeldía de género en Infamante Electra de Benjamín Galemiri /

Marcela Medina Bravo

Empapado

Vengo a ver a mi hijo de la diestra (...)

En este caso la metáfora del padre, institución, estado o Poder se subvierte o se desplaza a un campo emocional, de una madre, en una localidad llamada Chile que se resemantiza en amor, entrañas, empapado, etc.

En la óptica propuesta por Foucault, el poder es un sistema lineal/ transversal que abarca todos los esquemas sociales e individuales, así se puede entender la política no sólo en términos coyunturales-sociales, sino también como una impronta cultural en el campo de la sexualidad y género a partir de esquemas ideológicos poderosos que se constituyen a través del lenguaje.

Aun así, se reconoce en este tipo de discurso galemiriano una manifestación representativa de la figura del poder en una serie de significados constituidos en base a una serie de significantes que se entrecruzan y se desplazan en el habla (el poder va y viene) de los protagonistas. Mascarada del juego autorial.

Esto cabe en lo que, según Tannen (1996) al analizar el discurso hablado, se debe tener en cuenta el transfondo cultural que subyace en él, y éste puede ser potencialmente ambiguo y polisémico, sobre todo en ese ámbito, y con mayor razón aún si éste se manifiesta en el campo de la literatura.

Lo anterior sirve para poder localizarse y posicionarse en el ámbito del género, donde se han reconocido estrategias lingüísticas, que en el caso que ahora analizamos lo llamamos desplazamiento, focalizados en los conceptos de rebeldía y subversión. Conceptos que, de suyo, aparecen al margen del poder, puesto que configuran la idea de lo no estatuido, de lo no convencional, opuestos al orden y normativa que propugna el poder.

Es decir, el solo hecho de la actualización del mito en el contexto de nuestro siglo constituye una transgresión, porque nos encontramos acá con la oposición entre lo clásico y lo nuevo, resignificación e interpretación a la luz de nuevos contextos históricos, políticos y culturales. Es decir, el paradigma nominal metafórico Padre, institución, Estado, se rebela y subvierte en el caso propuesto, desde el principio, como Electra/Dafne. La primera debe demostrar su amor incondicional y deseante hacia su padre, pero al llamarse Dafne expresa de suyo la rebeldía motor de sus actos. La nominación impuesta por el padre se constituye así un boomerang, solo posible de ser entendido a la luz de las teorías 
de interpretación que tienen como basamento el psicoanálisis, cuestión que dejaremos por ahora de lado.

Sin embargo, todavía vemos un problema y que tiene que ver en que el origen de esta rebeldía se basa en al menos dos razones: la primera se debe a la inconsistencia social y lingüística del padre al no tener las respuestas deseadas y la segunda es el hecho de que la rebeldía implícita de Dafne implica un goce que no asume y que sólo es posible en cuestiones estrictamente lingüísticas discursivas, que no van más allá que el puro acto de habla. Su rebeldía se desparrama en órganos e imágenes y esto sólo es posible en la abjuración y el reproche ${ }^{11}$. Y éstas no son sustanciales, no son fundacionales, no son clásicas (he aquí la mascarada galemiriana). Así cuando ella se desplaza de su figura de hija, para pasar a la dominadora, protectora, defensora de la situación jurídica del padre, lo hace en base a inconsistencias lingüísticas/siquicas que se basan en apoyos emocionales, pero no jurídicos y convencionales, y cuando ella logra "saber" se vuelve inconclusa, "mujer" de necesidades emocionales. Volvemos al constructo y al juego sin retorno...

DAFNE:

Todo me parece polvoriento ahora

El país

Ya sabe lo que pienso

He oído decir lo mismo

Miles de veces

Solo que ahora soy yo la que lo repite

Puesto que he conocido a mi verdadera madre

Mientras soy invadida por una oleada de emociones

Inundada de una fétida melancolía.

Hubo una vez un hombre

Que no era mi padre.

Fíjate que me interesé en él (...)

De improviso empecé a sentirme exaltada

Sin motivo alguno

Un corazón palpitaba terriblemente

Estaba en el buen camino (la cursiva es mía)

En definitiva, se ha reconocido el leiv motiv del actuar de Dafne/Electra (nótese el cambio del paradigma binario). Dafne, en un principio no se hace cargo del mito, por cuanto políticamente, institucionalmente ella es la defensora de su padre (el deber), pero en su interior sólo desea

11 Kristeva (1999), Sentido y sin sentido de la rebeldía, Santiago, Editorial Cuarto Propio. 
Discurso, subversión y rebeldía de género en Infamante Electra de Benjamín Galemiri /

Marcela Medina Bravo

abjurar, infamar, cuestiones inconscientes adscritas a la rebeldía y la subversión pero que carecen de fundamentos instituidos a la luz de la visión pública, masculina y poderosa.

JOSHUA HALEVI:

¿Cuánto me costará mi libertad?

DAFNE:

Algo que te duela mucho.

El nombre de mi verdadera madre.

JOSHUA ALEVI:

Jamás pude hacerla temblar como la veo temblar ahora.

DAFNE:

Deja caer palabras.

JOSHUA ALEVI:

Comienza a fascinarme su crueldad, un beso, un beso, luego podrá irse... lo que hace todo un poco complicado, es que le ganaré este juego hija...

Evidentemente, en este segmento caemos en el juego de la incomunicación, Dafne ha sido explícita, su intención es conocer a su madre. Su padre en cambio se desplaza al lugar de poder, no lo había estado hasta ese momento, sabe que es este el punto de quiebre en la relación con su hija y solo allí puede dominar. El beso, el hacer temblar, el ganar, son sus estrategias.

Así, el Joshua ${ }^{12}$, aun como tal se impone pero sólo a través de la estrategia del sentimiento que provoca en Dafne. Es un juego de palabras que no expresan otra cosa que una ideología manipuladora a través del sentimiento. La hija, por su parte, se instaura poderosa, a cambio de la libertad (su libertad), saber el nombre de su madre, y cuando lo consigue a través del chantaje, abjuración y resentimiento deja de ser rebelde, subvertida, para transformarse en lo que se ha denominado "género femenino".

\section{Conclusiones}

Se pueden hacer varias lecturas de Infamante: subversión historiográfica literaria, rompe con el mito clásico, subversión de género literario; no

12 Quizás sea necesario señalar aquí dadas las condiciones mencionadas de los textos de Galemiri (intertexualidad caleidoscópica, imágenes, cultura, etc): el nombre de Joshua: Significa bendecido por el señor y que tiene como características que su corazón domina su cabeza. De gustos delicados y tiernos sentimientos, dulce y constante. Desarrolla sus empresas con energía. Cariñoso y gentil. (¿Oposición, juego?)

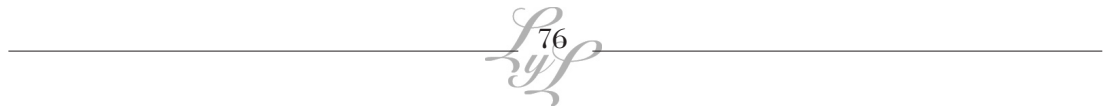


es precisamente una tragedia al estilo Aristóteles, subversión del concepto político como rechazo implícito al sistema contextual/ (actual) y subversión a las categorías de género estatuidas.

Sin embargo, es el lenguaje como acto de habla el que aparece, en primera instancia como el campo de acción para dicha subversión; por cuanto, en voz de Galemiri éste aparece así como una leyenda "bestial de la humanidad", y el habla de Dafne nos llevará a una tierra virgen y al prodigioso momento de la primera vez. ${ }^{13}$

Todo esto se puede corroborar a través de de gestos, sutilezas, movimientos, formas y ritmos de un lenguaje frenético y caótico (estrategias discursivas). Internalizado por la sujeto mujer que apela a la incomunicación basada en el reproche y la abjuración del deseo paterno. El discurso dialógico de la obra se mueve en un constante desplazamiento que se puede resumir en la relación metafórica de la oposición padre/hija.

Este destierro, este sujeto significante nómade, hija, recurre a los mismos mecanismos en los cuales se inserta, pareciera que no hay otra posibilidad de identificación. Su entrada en lo simbólico adquiere el matiz rebelde solo en cuanto hay un algo contra lo cual rebelarse, si esto desaparece, se deja de ser rebelde. La pregunta es dónde se queda. La solución que nos ofrece el texto es volver a la norma, a lo convencional, a reprimir la sexualidad. En definitiva reconocer al Edipo como la manifestación de las relaciones de género.

Entonces la estrategia a seguir en un principio, basada en el reconocimiento de la subversión de lo estatuido por un sistema político social imperante, expuesto en la situación contextual de la obra y reificado en el padre. Romper con la relación que se propugna por este mismo sistema, establecida en los dos personajes (hombre y mujer, padre e hija), que entremezclan juegos de poder y por último, lo más importante, romper con la categoría de género en el juego entre significado y significante, a través de la lectura de la impronta lúdica conceptual del habla de los personajes enfatizándola en la figura de Electra/Dafne, nos deja de manifiesto que sólo es posible en una búsqueda estética de prácticas discursivas micropolíticas de género vertebradas en torno a la experimentación de nuevas formas de relación con la alteridad, la ética, el saber y la memoria.

Realización que esta vez se da en el plano literario, pues en este es posible la inserción de la experimentación de formas de autorepresenta-

13 Arrabal (2006), Prefacio a Galemiri, en Infamante Electra, pp. 21-22. 
Discurso, subversión y rebeldía de género en Infamante Electra de Benjamín Galemiri /

Marcela Medina Bravo

ción que intentan romper de forma radical las categorías de género hegemónicas, yendo más allá de la manoseada denuncia de la opresión para propiciar y celebrar la explosión de modos de subjetividad atascadas o congeladas durante siglos en el reinado de lo Uno. Cuestión fundamental para entender el plano literario en el cual se mueve Galemiri.

Entonces es una responsabilidad política poner de manifiesto el distanciamiento, objetivación y problematización de la cadena de significados y el mantener la subversión creativa sobre todo a partir de un campo fértil para ello, como es la literatura y el arte en general.

En la relación padre/hija, la rebeldía, lo infamante, Dafne, no sólo por el hecho de que su adversario no se sostiene, que sus valores se han vaciado o son inconsistentes (está en la cárcel por corrupto), sino que por el hecho de que éste la hace apoderarse de su memoria y ésta está vacía. No hay un recuerdo concreto ni específico de identidad materna. Este hombre no solo la insertó en el campo de lo simbólico, sino que además es el obstáculo para acceder a aquello inconsciente inenarrable que es lo real. Por lo tanto la relación libidinal con el padre se quiebra al momento en que éste le niega el vínculo con la madre, el vínculo con la identificación. En el fondo Electra/Dafne es el sincretismo de la contradicción de género que hasta hoy subsiste y que según parece sólo el lenguaje y sus contradicciones metafóricas y metonímicas son capaces de explicitar.

El problema es que para muchos y muchas todavía esto no pasa de ser un juego, puesto que "si el modelo de una sexualidad antigenital (como lo que intentó hacer Dafne) y más difusa es la única opción de oposición a la estructura hegemónica de la sexualidad, ¿en qué medida está esa relación binaria obligada a reproducirse de manera interminable? ¿Qué posibilidad existe de alterar la oposición binaria en sí? ${ }^{14}$

Entonces, Electra/Dafne es la significación de una falta, significada por lo simbólico, que no es más que un conjunto de reglas lingüísticas diferenciadoras que generan diferencia sexual. Sin embargo, siempre hay un entrecruce entre los polos metafórico y metonímico y es en ese punto cuando lo femenino se fija, se inmutabiliza. Existe la dispersión, existe la rebeldía, existe el desplazamiento, pero como se ha dicho, al parecer sigue siendo solo un juego de significancias, por lo menos es el juego en el que nos hizo entrar Galemiri.

14 Butler (2008), El género en disputa, Barcelona, pág. 88. 


\section{Bibliografía Básica}

Galemiri, B. (2006). Infamante Electra, Ese discreto Ego culpable (2006), Santiago, Chile, editorial Cuarto Propio.

(1998). Antología, Santiago, Chile, Ediciones teatrales.

\section{Bibliografía Crítica}

Arrabal, F. (2006). Prefacio a Galemiri en Infamante Electra, Santiago, Chile, Cuarto Propio.

Bonder, G. (1998). Género y subjetividad: avatares. de una relación no evidente. En: Género y Epistemología: Mujeres y Disciplinas, Santiago, Chile. Programa Interdisciplinario en Estudios de Género, Universidad de Chile.

Buttler, J. (2007). El género en disputa, el feminismo y la subversión de la identidad, Barcelona, España, Paidós.

Feminismo y Democracia, en Entre la metonimia del mercado y la metáfora (imposible) de la revolución. En http://www. ft.org.ar/estrategia/ei20/ei20feminismo.htm

Foucault, M. (1980). El orden del discurso (segunda edición), Madrid, España, Tusquet editores.

Jakobson, R. (1967). Fundamentos del Lenguaje. Madrid, España, Ciencia Nueva.

Kristeva, J. (1999). Sentido y sin sentido de la rebeldía, Santiago, Chile, Editorial Cuarto Propio.

Rojo, G. (2001). Diez tesis sobre la crítica, Santiago, Chile, Editorial Lom,

Sirven, R., F. Polzenhagen et al. (2010). Cognitive, linguistics, ideology, and critical discourse analysis en The Oxford Handbook of Cognitive Linguistics, Edited by Dirk Geeraerts and Herbert Cuyckens, Paperback, 1368 pages.

Spivak, G. (2008). El desplazamiento en el discurso de la mujer. Recuperado 4/23/2010 de http://www.Caosmosis.acracia.net

Tannen, D. (1996). La relatividad de las estrategias lingüisticas: repensar el poder y la solidaridad en el género y la dominación en Género y discurso, Barcelona, España, Paidós Ibérica. 